

\section{EDITORS}

Asaf Goldschmidt, Department of East Asian Studies,

Tel Aviv University

Alexandre Métraux, Archives Henri Poincaré, Université Nancy 2, France

Jürgen Renn, Max-Planck-Institut für Wissenschaftsgeschichte, Berlin

ASSISTANT EDITOR

Michael Elazar, Max-Planck-Institut für Wissenschaftegeschichte, Berlin

\section{EDITORIAL BOARD}

Mohammed Abattouy, Fez University, Morocco

Jed Z Buchwald, California Institute of Technology

Robert S Cohen, Boston University

Leo Corry, Tel Aviv University

Lorraine Daston, Max-Planck-Institut für

Wissenschaftsgeschichte, Berlin

Jean-Claude Dupont, University of Amiens, France

Sven Dupré, University of Ghent, Belgium

Yehuda Elkana, Central European University,

Budapest, Hungary

Rivka Feldhay, Tel Aviv University

Gideon Freudenthal, Tel Aviv University
Peter L. Galison, Harvard University

Paolo Galluzzi, University of Florence, Italy

Giora Hon, University of Haifa, Israel

Thomas P Hughes, University of Pennsylvania

Irina Podgorny, Universidad de La Plata, Argentina

Roger Smith, Academy of Sciences, Moscow

Baichun Zhang, Chinese Academy of Sciences, Beijing

\section{Managing Editor}

Miriam Greenfield, The Cohn Institute for the History and Philosophy of Science and Ideas, Tel Aviv University

Science in Context acknowledges the support of Bertram J and Barbara Cohn of the Cohn Institute for the History and Philosophy of Science and Ideas, and the support of the Van Leer Jerusalem Institute.

\section{SUBSCRIPTIONS}

Science in Context (ISSN 0269-8897) is published four times a year in March, June, September and December. Four parts form a volume. The subscription price which includes electronic access and delivery by air where appropriate (but excluding VAT) of volume 24 is $£ 187$ (US \$334 in USA, Canada and Mexico) for institutions; $£ 52$ (US \$83) for individuals ordering direct from the publishers and certifying that the journal is for their personal use. The electronic only price available to institutional subscribers is $£ 171$ (US \$301 in USA, Canada and Mexico). Single parts are £49 net (US \$88 in USA, Canada and Mexico) plus postage. EU subscribers (outside the UK) who are not registered for VAT should add VAT at their country's rate. VAT registered members should provide their VAT registration number. Japanese prices for institutions (including ASP delivery) are available from Kinokuniya Company Ltd, PO. Box 55, Chitose, Tokyo 156, Japan.

Orders, which must be accompanied by payment, may be sent to a bookseller, subscription agent or direct to the publisher: Cambridge University Press, The Edinburgh Building, Shaftesbury Road, Cambridge CB2 8RU; or in the USA, Canada and Mexico: Cambridge University Press, Journals Fulfillment Department, 100 Brook Hill Drive, West Nyack, New York 10994-2133. Application to Mail at Periodicals Postage Rates is Pending at New York, NY.

\section{COPYING}

This journal is registered with the Copyright Clearance Center, 222 Rosewood Drive, Danvers, MA 01923, USA. Organizations in the USA who are also registered with the C.C.C. may, therefore copy material (beyond the limits permitted by sections 107 and 108 of U.S. Copyright law) subject to payment to the C.C.C. of the per copy fee of $\$ 12.00$. This consent does not extend to multiple copying for promotional or commercial purposes. Code 0269-8897/2011 \$12.00. ISI Tear Sheet Service, 3501 Market Street, Philadelphia, PA 19104, USA, is authorized to supply single copies of separate article for private use only. Organizations authorized by the Copyright Licensing Agency may also copy material subject to the usual conditions. For all other use, permission should be sought from Cambridge or from the American Branch of Cambridge University Press.

\section{INTERNET ACCESS}

Science in Context is included in the Cambridge Journals Online service at http://journals.cambridge.org For information on the other Cambridge titles access http://www.cambridge.org

This journal issue has been printed on FSC-certified paper and cover board. FSC is an independent, non-governmental, not-for-profit organization established to promote the responsible management of the world's forests. Please see www.fsc.org for information. 


\title{
SCIENCE IN CONTEXT
}

\author{
VOLUME 24 NUMBER 2 JUNE 2011
}

\section{Lay Participation in the History of Scientific Observation}

Guest Edited by Jeremy Vetter

Jeremy Vetter: Introduction: Lay Participation in the History of Scientific Observation

Brita Brenna: Clergymen Abiding in the Fields: The Making of the Naturalist Observer in Eighteenth-Century Norwegian Natural History

Simon Werrett: Watching the Fireworks: Early Modern Observation of Natural and Artificial Spectacles

Oliver Hochadel: Watching Exotic Animals Next Door: "Scientific" Observations at the Zoo (ca. 1870-1910)

Victoria Cain: The Art of Authority: Exhibits, Exhibit-Makers, and the Contest for Scientific Status in the American Museum of Natural History, $1920-1940$

Jenny Beckman: Collecting Standards: Teaching Botanical Skills in Sweden, 1850-1950

Jeremy Vetter: Lay Observers, Telegraph Lines, and Kansas Weather: The Field Network as a Mode of Knowledge Production

Emmanuel Didier: Counting on Relief: Industrializing the Statistical Interviewer during the New Deal

Cover illustration: View of Mount Cayambe, Ecuador ("Vue du Cajambé"), from: Alexander von Humboldt: Vues des Cordillères, et monumens des peuples indigènes de l'Amérique. Paris: F. Schoell, 1810, pl. XLII, drawn by Pierre-André Marchais after a sketch by von Humboldt and engraved by Louis Bouquet. 